\title{
Transfer by grafting of the effect of thermal induction of generative development in winter rape (Brassica napus var. oleifera L.)
}

\section{FRANCISZEK DUBERT ${ }^{1}$, SEBASTIAN PIENKOWSKI ${ }^{1}$, WLADYSLAW FILEK ${ }^{2}$}

${ }^{1}$ Department of Plant Physiology, Polish Academy of Sciences, ul. Podłużna 3, 30-239 Kraków, Poland

${ }^{2}$ Department of Plant Physiology, Agricultural University, ul. Podłużna 3, 30-239 K-raków, Poland

〈Received: December 11, 1981〉

Abstract

The feasibility was studied of transferring the flowering factor in winter rape from vernalized plants to plants in which generative development was not induced by cold treatment. In a series of grafts made under field conditions scions from nonvernalized plants were grafted into stems of vernalized ones at the phase of bud and flower formation. Nonvernalized scions adopted the ability to generative development from vernalized stock. The transfer of the flowering stimulus was more effective in the case of grafts performed at the top of cut off stems than in the case of scions grafted on the side of a stem. The activity of the flowering factor in vernalized plants was the highest at or just before the bud formation phase. The responsiveness to the flowering factor transferred from vernalized stock was highest in 60- to 80-day-old scions. Analysis of the effect of age of the stock on the duration of the particular generative phases in grafted scions indicates that in vernalized plants of winter rape there may be more than one transferable factor that enables full generative development.

\section{INTRODUCTION}

Thermo-induction of generative development in plants has been studied for about fourty years but the mechanism of the process still remains unknown. The experiments conducted by $\mathrm{M}$ e $\mathrm{l} \mathrm{c}$ h e $\mathrm{r} \mathrm{s}\langle 1937 ; 1939\rangle$ have substantiated the hypothesis that in winter plants a certain substance 〈vernaline〉 is formed that conditions their flowering. $\mathrm{Me} \mathrm{l} \mathrm{chers}$ induced flowering in biennal, nonvernalized plants of Hyoscyamus niger $\mathrm{L}$. by grafting them with annual or biennal, vernalized plants of the same species. The feasibility of transferring the flowering ability to nonvernalized winter plants was also confirmed in other experiments, in which grafts were made between plants of the same, or even different species. A v a $\mathrm{k}$ y a $\mathrm{n}\langle 1950\rangle$ reported the flowering of cabbage in the first year of growth when grafted on mustard plants and of carrot in the first year when grafted on dill plants as stock. Similar results were obtained with 
nonvernalized cabbage grafted on spring rape, white mustard, vernalized cabbage and radish $\langle\mathrm{K}$ v a s $\mathrm{n}$ i k o v, 1952; $\mathrm{K} \mathrm{r} \mathrm{u} \mathrm{zh}$ il i $\mathrm{n}$ and $\mathrm{S} \mathrm{h}$ ve d$\mathrm{s} \mathrm{k}$ a y a, 1960; R a z u m o v, 1959 $\rangle$, and with nonvernalized chrysanthemum grafted on vernalized plants of this species $\langle\mathrm{S} \mathrm{chw}$ a be, 1954 $\rangle$. $\mathrm{M}$ a r g a $\mathrm{r}$ a $\langle 1960\rangle$ reported transfer of the flowering stimulus from vernalized stock to nonvernalized scions in beet. $\mathrm{C} \mathrm{h}$ a i $1 \mathrm{a} \mathrm{k} \mathrm{h} \mathrm{y} \mathrm{a} \mathrm{n}\langle 1955\rangle$ and $\mathrm{Ch}$ a i l a k h y a n and K h lo pe n k o va $\langle 1957$ induced flowering in scions from nonvernalized winter rape plants grafted on spring rape or Abyssinian cabbage.

In these reports information is limited to the conditions that have to be observed in order to transfer the flowering factor by grafting the plants. They do not refer, however, to the dynamics of the particular phases in generative development of grafted plants. The purpose of our investigation was thus:

- to check whether in winter rape the flowering factor can be transferred by graftings from vernalized to nonvernalized plants and whether such experiments can be carried out under field conditions, and

- to determine the influence of the age of vernalized stock and of nonvernalized scions on the generative development of grafted plants and also on the dynamics of the particular phases of generative development.

\section{MATERIAL AND METHODS}

Winter rape cv. 'Górczański' was taken for experiments carried out in 1979 and 1980. Stock plants were vernalized under natural conditions in the field. Scions were taken from plants grown under conditions preventing vernalization, i.e. in a glass-house at a temperature of 17 to $21 \mathrm{C}$, under 14-hour day light and air humidity of 60 to 70 per cent. Grafts were made at intervals of three days in experiment no. 1 in 1979, and of about one week in experiment no. 2 in 1980. The age of plants, from which scions were taken, varied from 37 to 60 days in experiment no. 1 and from 30 to 98 days in experiment no 2 . In every series of nonvernalized plants used for scions a certain number of specimens were planted out in the field to control their inability of generative development. In all the instances these controls remained in the vegetative phase till the end of the experiment.

In experiment no. 1 grafts were made either by a wedge shaped incision at the top of the stem where its upper part was removed or by implanting the scion in the axil at a point half way up the stem where a side bud was removed without decapitating the top part. In experiment no. 2 only the former method was applied. The point of grafting was bandaged with medical plaster. For a week after grafting the plants were wrapped in transparent plastic bags in order to reduces transpiration. When a graft was successful the stock was gradually deprived of all side shoots at intervals of two to three days and leaves longer than 
3 centimetres were cut off from the transplants $\langle\mathrm{C} \mathrm{h}$ a i l a $\mathrm{k} \mathrm{h}$ y a $\mathrm{n}, 1955\rangle$. Observations of grafted plants were repeated also every two or three days and the dates of bud, flower and silique formation on the transplants were recorded. Since daylength did not change significantly in the course of the experiments $<$ May. June, July $>$ the effect of this factor on plant development was disregarded.

\section{RESULTS}

Both methods of grafting resulted in complete or partial generative development of transplants. Transplants grafted at the top of stems $\langle$ Fig. 1$\rangle$ passed to the generative phase in about $80^{\circ}$ and those at the side of stems in about $68^{\circ}$ " of successful graftings. A certain number of transplants $\left\langle\right.$ about $7.5^{\circ}$ in top graftings and $16 \%$ in side graftings $>$ remained alive to the end of the experiment but did not

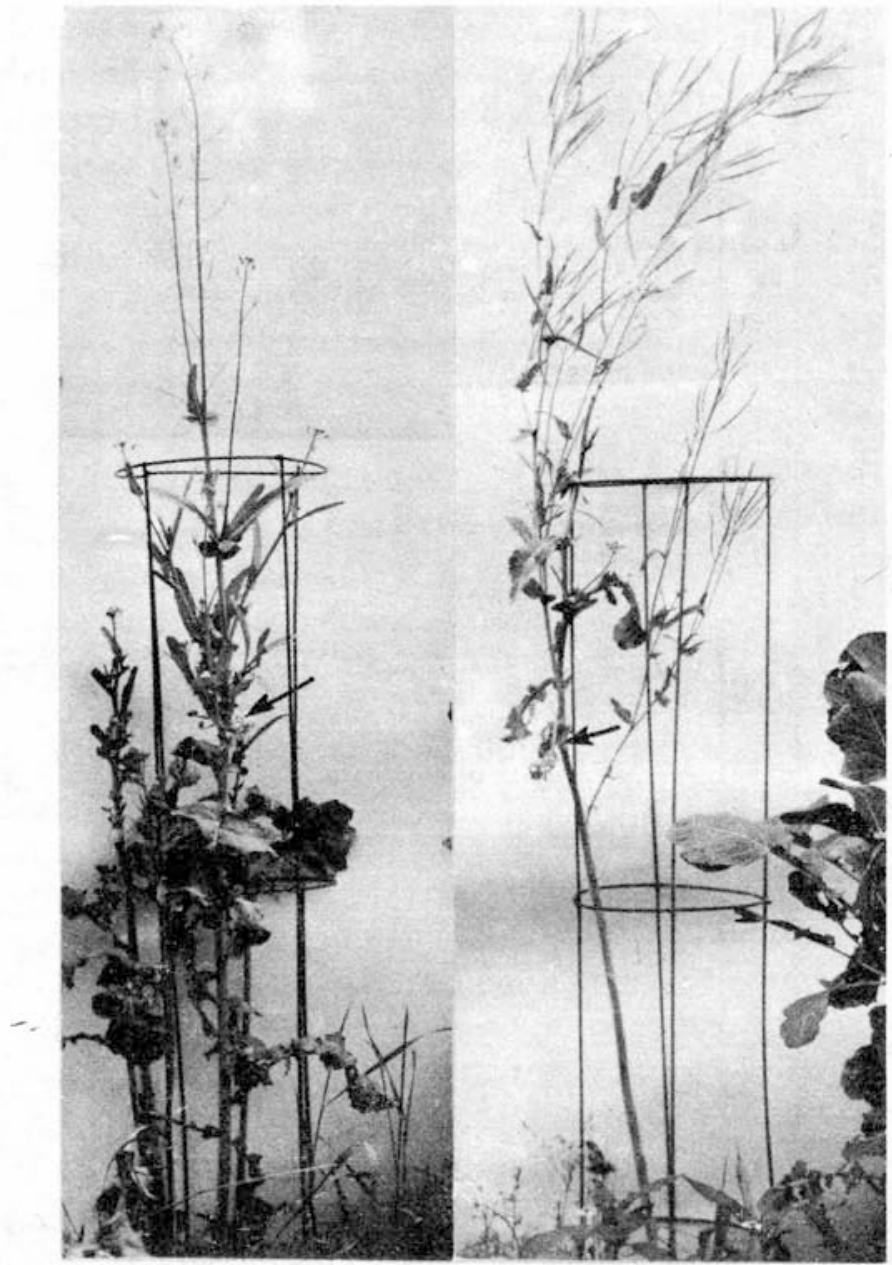

Fig. 1. Flowers and siliques on nonvernalized scions of winter rape grafted on vernalized stock 
Table 1

Generative development of nonvernalized scions of winter rape grafted on vernalized stock. Experiment No. 1 (1979)

\begin{tabular}{|c|c|c|c|c|c|c|c|c|c|c|c|c|c|c|}
\hline \multirow{3}{*}{$\begin{array}{l}\text { Date of } \\
\text { grafting* }\end{array}$} & \multirow{3}{*}{$\begin{array}{l}\text { Age of } \\
\text { scions } \\
\text { (days) }\end{array}$} & \multirow{3}{*}{$\begin{array}{l}\text { Number } \\
\text { of } \\
\text { grafted } \\
\text { scions }\end{array}$} & \multirow{3}{*}{$\begin{array}{c}\text { Number } \\
\text { of } \\
\text { successful } \\
\text { grafts }\end{array}$} & \multirow{3}{*}{$\begin{array}{l}\text { Number } \\
\text { of } \\
\text { scions } \\
\text { forming } \\
\text { genera- } \\
\text { tive } \\
\text { organs }\end{array}$} & \multirow{3}{*}{$\begin{array}{c}\text { Number of } \\
\text { scions } \\
\text { forming ge- } \\
\text { nerative } \\
\text { organs as \% } \\
\text { of successful } \\
\text { grafts }\end{array}$} & \multicolumn{3}{|c|}{$\begin{array}{l}\% \text { of scions ending } \\
\text { generative development } \\
\text { after formation of }\end{array}$} & \multicolumn{6}{|c|}{$\begin{array}{c}\text { Number of days from grafting to particular } \\
\text { developmental phases in scions ending vegetation } \\
\text { after formation of }\end{array}$} \\
\hline & & & & & & \multirow{2}{*}{ buds } & \multirow{2}{*}{ flowers } & \multirow{2}{*}{ siliques } & \multirow{2}{*}{$\frac{\text { buds }}{\text { buds }}$} & \multicolumn{2}{|c|}{ flowers } & \multicolumn{3}{|c|}{ siliques } \\
\hline & & & & & & & & & & buds & flowers & buds & flowers & siliques \\
\hline \multicolumn{15}{|c|}{ Grafting at top of decapitated stems } \\
\hline May 5 & 37 & 41 & 22 & $\begin{array}{c}15 \\
(100)\end{array}$ & 68.2 & 6.7 & 13.3 & 80.0 & 60.0 & 48.0 & 81.0 & 38.8 & 50.5 & 82.5 \\
\hline May 7 & 39 & 59 & 42 & $\begin{array}{c}31 \\
(100)\end{array}$ & 73.8 & 6.5 & 12.9 & 80.6 & 48.0 & 38.5 & 58.3 & 33.5 & 46.3 & 77.1 \\
\hline May 11 & 43 & 51 & 19 & $\begin{array}{c}19 \\
(100)\end{array}$ & 100.0 & 31.6 & 10.4 & 58.0 & 64.5 & 39.5 & 62.5 & 31.0 & 44.3 & 68.6 \\
\hline May 15 & 47 & 55 & 19 & $\begin{array}{c}19 \\
(100)\end{array}$ & 100.0 & 5.3 & 5.3 & 89.4 & 56.0 & 42.0 & 50.0 & 33.6 & 46.7 & 72.1 \\
\hline May 17 & 36 & 60 & 11 & $\begin{array}{c}11 \\
(100)\end{array}$ & 100.0 & 9.1 & 27.3 & 63.6 & 91.0 & 42.0 & 59.0 & 29.0 & 42.3 & 64.0 \\
\hline May 19 & 38 & 53 & 4 & $\begin{array}{c}2 \\
(100)\end{array}$ & 50.0 & 50.0 & - & 50.0 & 53.0 & - & - & 36.0 & 47.0 & 63.0 \\
\hline \multicolumn{15}{|c|}{ Grafting at side of stems } \\
\hline May 10 & 42 & 52 & 24 & $\begin{array}{c}21 \\
(100)\end{array}$ & 87.5 & 47.6 & 9.5 & 42.9 & 61.8 & 44.0 & 58.0 & 36.2 & 49.8 & 72.0 \\
\hline May 14 & 60 & 55 & 11 & $\begin{array}{c}5 \\
(100)\end{array}$ & 45.5 & 80.0 & 20.0 & 0.0 & 73.8 & 36.0 & 51.0 & - & - & - \\
\hline May 16 & 48 & 56 & 22 & $\begin{array}{c}11 \\
(100)\end{array}$ & 50.0 & 90.9 & 9.1 & 0.0 & 71.8 & 37.0 & 50.0 & - & - & - \\
\hline May 18 & 37 & 49 & 14 & $\begin{array}{c}11 \\
(100)\end{array}$ & 78.6 & 27.3 & 0.0 & 72.7 & 56.3 & - & - & 15.9 & 48.5 & 73.1 \\
\hline
\end{tabular}

*Phase of development of stock at different grafting dates: May 5-7 - developed flower buds, May 10-16 - beginning of flowering, May 17.19 - full bloom. 
form new leaves and developed very slowly; subsequent examination revealed that these scions did not unite with the stock but developed roots, which grew into the air ducts of the stock. Successful graftings, as measured in percentages of accepted transplants, declined in the successive series of graftings $\langle$ Table 1$\rangle$. It may be assumed that this was largely due to the progressing age of stock plants and thus to the phase of growth, in which stock stems become lignified and develop air ducts. Such changes probably hindered union of scions with stock and favoured root formation by scions. In the case of apical grafts the time interval form grafting to bud, later flower and silique formation decreased in the successive series of graftings.

Considerable differences were observed in the duration of the particular phases of generative development. Regardless of the method of graftings, plants that produces siliques in the course of the experiment formed flower buds on the avarage 30 days earlier than those, which at the end of the experiment were still in the phase of developed buds, and about six days earlier than plants, which at the end of the experiment had well developed flowers $\langle$ Table 1$\rangle$.

In the case of side graftings older scions, i.e. those aged 48 or 60 days, never developed siliques; their development usually ended after the buds had formed. On the other hand, after apical grafting scions of a similar age $\langle 47$ days $\rangle$ went through all the developmental phases. This shows that the apical method of grafting is more suitable for transferring the flowering factor from vernalized to nonvernalized plants.

The results of the second experiment are listed in Table 2 and illustrated in Figure 2. The proportion of scions with generative development was in most cases similar to that in the first experiment. Experiment no. 2 shows that the generative development of scions is affected both by the date of graftings <age of stock plants $>$ and the age of scions. The highest percentage of plants in the generative phase was obtained in series I, i.e. when grafts were made on May 12 in the early phase of bud formation with the use of scions 60 to 80 days old. In the case of grafts made at later dates the optimum age of scions was 70 to 80 days. Regardless of their age the quickest to pass to the generative phase were scions grafted on stock plants at the beginning of the flowering phase $<$ Fig. $2 b$, series II and III $\rangle$. Figure $2 b$ also shows a certain influence of the age of stock plants on the rate of bud formation after the different grafting dates. Earliest bud formation occurred when scions for grafting were taken after about 60 days of growth. Within the scion age range from 50 to 90 days the time necessary for plants to pass from the phase of buds to that of flowers was reduced after the later grafting dates $\langle$ Fig. $2 c\rangle$. This was most apparent in series IV, in which the time between bud formation and flowering was only about one half of what it was in the previous series of graftings. The time needed for flowers to form siliques $\langle$ Fig. $2 d>$ was shorter after each successive grafting date, with the exception of the last grafting. The age of scions had no major influence on the rate of generative development after the beginning of bud formation. 
Table 2

Generative development of nonvernalized scions of winter rape grafted on vernalized stock. Experiment No. 2 (1980)

\begin{tabular}{|c|c|c|c|c|c|c|c|c|c|c|}
\hline \multirow{2}{*}{$\begin{array}{c}\text { Series } \\
\text { and date } \\
\text { of } \\
\text { grafting* }\end{array}$} & \multirow{2}{*}{$\begin{array}{l}\text { Age } \\
\text { of } \\
\text { scions } \\
\text { (days) }\end{array}$} & \multirow{2}{*}{$\begin{array}{l}\text { Number } \\
\text { of suc- } \\
\text { cessful } \\
\text { grafts }\end{array}$} & \multirow{2}{*}{$\begin{array}{c}\text { Number } \\
\text { of } \\
\text { scions } \\
\text { forming } \\
\text { generative } \\
\text { organs }\end{array}$} & \multirow{2}{*}{$\begin{array}{l}\text { Number } \\
\text { of scions } \\
\text { forming } \\
\text { genera- } \\
\text { tive } \\
\text { organs as } \\
\% \% \text { of } \\
\text { succes- } \\
\text { sful } \\
\text { grafts }\end{array}$} & \multicolumn{3}{|c|}{$\begin{array}{l}\text { \% of scions ending } \\
\text { generative development } \\
\text { after } \\
\text { formation of }\end{array}$} & \multicolumn{3}{|c|}{$\begin{array}{l}\text { Number of days from } \\
\text { grafting to formation o }\end{array}$} \\
\hline & & & & & buds & flowers & siliques & buds & flowers & siliques \\
\hline \multirow{4}{*}{$\begin{array}{c}\text { I } \\
\text { May } 12 \\
\vdots\end{array}$} & 41 & 24 & $\begin{array}{c}12 \\
(100)\end{array}$ & 50.0 & 25.0 & 16.7 & 58.3 & 51.5 & 60.0 & 76.0 \\
\hline & 51 & 43 & $\begin{array}{c}34 \\
(100)\end{array}$ & 79.1 & 2.9 & 0.0 & 97.1 & 40.6 & 56.6 & 76.0 \\
\hline & 59 & 48 & $\begin{array}{c}46 \\
(100)\end{array}$ & 95.8 & 0.0 & 0.0 & 100.0 & 39.5 & 34.5 & 76.1 \\
\hline & 73 & 49 & $\begin{array}{c}44 \\
(100)\end{array}$ & 90.1 & 4.5 & 2.3 & 93.2 & 42.8 & 57.7 & 78.0 \\
\hline \multirow{4}{*}{$\begin{array}{c}\text { II } \\
\text { May } 19\end{array}$} & 48 & 48 & $\begin{array}{r}35 \\
(100)\end{array}$ & 72.9 & 0.0 & 5.7 & 94.3 & 37.2 & 52.6 & 70.2 \\
\hline & 58 & 42 & $\begin{array}{r}23 \\
(100)\end{array}$ & 54.8 & 0.0 & 13.0 & 87.0 & 36.8 & 51.6 & 70.4 \\
\hline & 66 & 48 & $\begin{array}{r}33 \\
(100)\end{array}$ & 68.7 & 0.0 & 9.1 & 90.9 & 38.6 & 54.5 & 70.6 \\
\hline & 80 & 47 & $\begin{array}{r}30 \\
(100)\end{array}$ & 63.8 & 3.3 & 0.0 & 96.7 & 39.7 & 53.3 & 72.8 \\
\hline \multirow{4}{*}{$\begin{array}{l}\text { III } \\
\text { May } 27\end{array}$} & 56 & 53 & $\begin{array}{c}15 \\
(100)\end{array}$ & 28.3 & 0.0 & 0.0 & 100.0 & 39.5 & 53.7 & 66.0 \\
\hline & 66 & 53 & $\begin{array}{r}23 \\
(100)\end{array}$ & 43.4 & 4.3 & 4.3 & 91.4 & 39.5 & 53.0 & 65.4 \\
\hline & 74 & 63 & $\begin{array}{c}43 \\
(100)\end{array}$ & 68.2 & 2.3 & 7.0 & 90.7 & 39.9 & 55.2 & 64.1 \\
\hline & 88 & 51 & $\begin{array}{c}30 \\
(100)\end{array}$ & 58.8 & 6.7 & 3.3 & 90.0 & 42.7 & 56.8 & 68.5 \\
\hline \multirow{4}{*}{$\begin{array}{c}\text { IV } \\
\text { June } 8\end{array}$} & 68 & 57 & $\begin{array}{c}18 \\
(100)\end{array}$ & 31.6 & 50.0 & 11.1 & 38.9 & 42.9 & 49.6 & 65.3 \\
\hline & 78 & 59 & $\begin{array}{c}21 \\
(100)\end{array}$ & 35.6 & 38.1 & 0.0 & 61.9 & 42.7 & 48.9 & 67.5 \\
\hline & 86 & 62 & $\begin{array}{c}14 \\
(100)\end{array}$ & 22.6 & 35.7 & 21.4 & 42.9 & 42.1 & 51.1 & 63.0 \\
\hline & 100 & 53 & $\begin{array}{c}2 \\
(100)\end{array}$ & 3.8 & 0.0 & 0.0 & 100.0 & 49.0 & 60.0 & 70.0 \\
\hline
\end{tabular}

*Phase of development of stock at different grafting dates: May 12 - developed flower buds, May 19 - beginning of flowering, May 27 - full bloom, June 8 - end of flowering. 

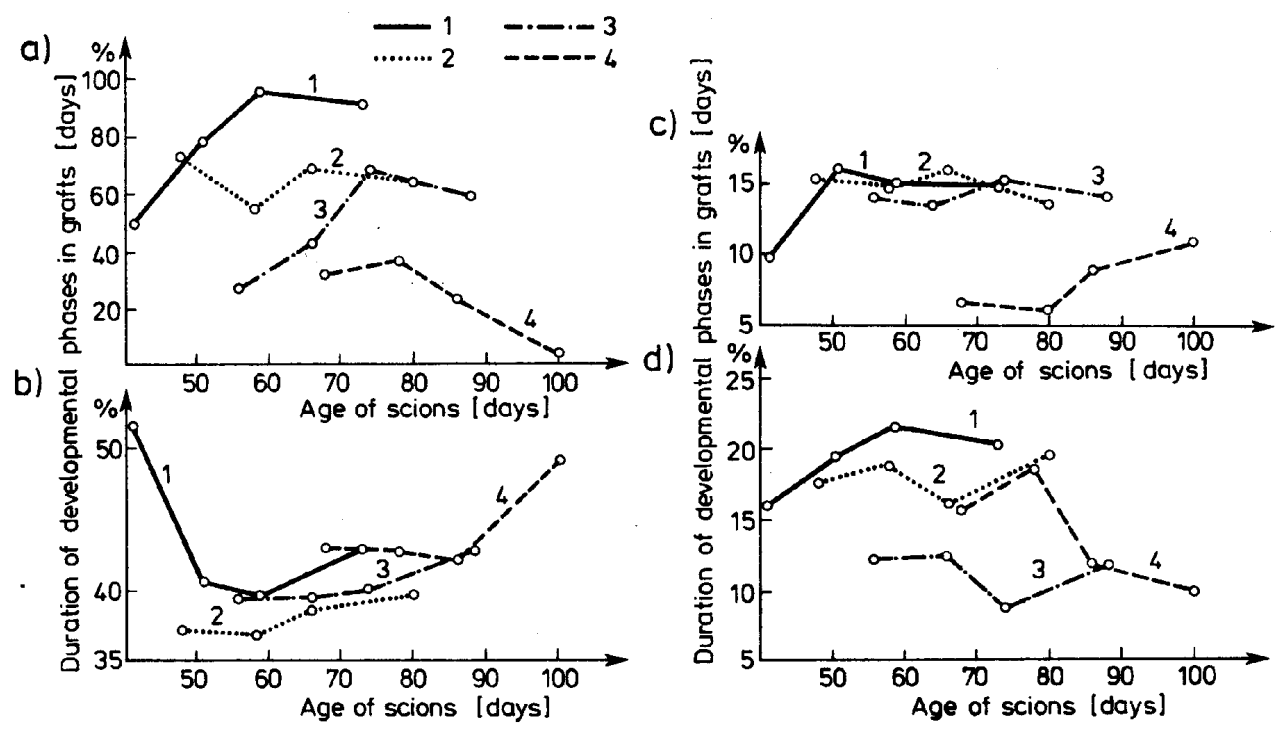

Fig. 2. Effect of scion and stock age on generative development of nonvernalized winter rape plants grafted onto vernalized plants; $\mathrm{a}-\%$ of plants forming generative organs, $\mathrm{b}$ - time from grafting to bud formation, c - time from bud formation to flowering, $d$ - time from flowering to silique formation; 1 - Series I, May 12; 2 - Series II, May 19; 3 - Series III, May 27; 4 - Series IV, June 8

\section{DISCUSSION}

Our experiments confirm the results reported by authors quoted earlier in this report that stimulation of flowering in plants can be transferred by grafting. $\mathrm{Ch}$ a il a kh y $\mathrm{n}\langle 1955$ ) and $\mathrm{Chailakhyan}$ and $\mathrm{Khlopen-}$ $\mathrm{k}$ o v a $\langle 1957\rangle$ report that flowering can be induced in nonvernalized winter rape by grafting either on spring rape plants or on vernalized winter rape plants. Our experiments have shown, moreover, that grafting of plants in experiments with transfer of the ability to flower induced by cold treatment can be carried out under field conditions and do not require air conditioned chambers.

The success of transferring the flowering factor depends on the age of the cold treated stock plants rather than on the age of the nonvernalized scions. Grafting was over three times more successful in the case of young stock plants at the phase of bud formation than in the case of the oldest stock plants at the phase of flowering. The reason may be either: (a) lignification of stock tissue with progressing age, which makes the union with the graft more difficult and thus limits the transfer of the flowering factor, or (b) ageing of leaves of stock plants and consequently their lower physiological activity. 
The influence of leaves of stock plants on the generative development of nonvernalized scions is confirmed by $\mathrm{A} v \mathrm{v} \mathrm{k}$ y a $\mathrm{n}\langle 1950\rangle$ and $\mathrm{C} \mathrm{h}$ a i l a k$\mathrm{h}$ y a $\mathrm{n}\langle 1955\rangle$. Our experiments also indicate that success of grafting, as estimated from the number of plants forming generative organs and from the time necessary for bud formation, depends both on the age of scions and on the age of stock plants $\langle$ Fig. $2 a$ and $b\rangle$. The optimum age of scions ranges from about 60 days for younger stock plants to about 80 days for older stock. In a certain number of grafted plants the development stopped at the phase of buds or of flowers $\langle$ Table 2$\rangle$.

When grafting on older stock plants resulted in bud formation, the further generative development was more rapid than when younger stock was used. This seems to indicate that plants have more than one factor responsible for their full generative development induced by cold treatment. According to this hypothesis the activity of the factor controlling the early phases of generative development is limited with the progressing age of plants, and at the same time the activity of the factor controlling the later phases is enhanced. This interpretation of our results is related to $\mathrm{C} \mathrm{h}$ a i l a k h y a n's $\langle 1964\rangle$ view that the ability of plants to flower as a result of photoperiodic induction depends on the formation in sufficient quantities of two different factors - gibberellins and anthesins.

The observed relations can also be interpreted according to the hypothesis that they are caused by a changing concentration of the flowering inhibitor in nonvernalized scions parallelly to their age and by changes in the rate of supply of the flowering factor from stock to scion. Another interpretation would refer to the possible influence of the age of scions and stock on the rate of transfer and further replication of the flowering factor. To elucidate these problems further investigations would be necessary.

The results reported here justify the following conclusions:

1. Nonvernalized plants of winter rape grafted on vernalized stock under field conditions adopt the ability of generative development.

2. Transfer of the flowering stimulus from vernalized stock to nonvernalized scions is more effective with grafts at the top of decapitated stems than with those at the side of stems.

3. The activity of the flowering factor in winter rape after vernalization is the highest during or before the phase of bud formation.

4. The response to the flowering factor transferred from vernalized stock is the highest in nonvernalized 60- to 80-day-old scions.

5. Analysis of the relation between the duration of different phases of generative development in scions and the age of stock plants leads to a preliminary hypothesis that in vernalized winter rape there is more than one factor conditioning full generative development of plants. 


\section{REFERENCES}

A v a k y a n A. A., 1950. Cvetenie dvukhletnikh kultur v pervom godu zhizni. Agrobiologiya 2: $12-21$.

$\mathrm{C}$ h a i l a k h y a n M. Kh., 1955. Razvitie ozimykh pri ich privivkakh na yarovye formy. Fiziol. Rast. 2: 235-266.

C h a i 1 a k h y a n M. Kh., 1964. Florigen, gibberelins and anthesis. Coloq. Internat. Centre Nat. Res. Scient. 123: 589-596.

C h a i l a k h y a $\mathrm{n}$ M. Kh., K h lo p e $\mathrm{n} \mathrm{k} \mathrm{o} \mathrm{va} \mathrm{L.} \mathrm{P.,} \mathrm{1957.} \mathrm{O} \mathrm{roli} \mathrm{listev} \mathrm{v} \mathrm{razvitii} \mathrm{ozimykh}$ rastienii. Doklady AN SSSR 112: 774-776.

K r u zh i l i n A. S., S hvedska y a Z. M., 1960. Rol listev v yarovizacii ozimykh i dvukhletnikh rastienii. Fiziol. Rast. 7: 287-295.

K v a s n i k ov B. V., 1952. Privivki dvukhletnikh rastienii na odnoletnie $i$ odnoletnikh na dvukhletnie. Agrobiologiya 4: 135-138.

M a r g a r a J., 1960. Recherches sur le determinisme de l'elongation et de la floraison dans le geure Béta. Ann. Amél. Plantes 〈Ann. Inst. Nat. Tech. Agron., Ser. B〉 10: 361-471.

M e $1 \mathrm{c}$ h e r s G., 1937. Die Wirkung von Genen, tiefen Temperaturen und Blühenden Pfropartern auf die Blühreife von Hyoscyamus niger L. Biol. Zbl. 57: 568-614.

M e 1 c h e r s G., 1939. Die Blühhormone. Ber. Dtsch. Bot. Ges. 57: 29-48.

R a z u m ov V. I., 1959. Ob uskorenii razvitiya ovoshchnykh dvukhletnikh rastienii pri privivkakh. Tr. Prikl. Bot. Gen. i Selekcii 32: 89-96.

$\mathrm{S} \mathrm{c} \mathrm{h} \mathrm{w} \mathrm{a} \mathrm{b} \mathrm{e} \mathrm{W.} \mathrm{W.,} \mathrm{1954.} \mathrm{The} \mathrm{site} \mathrm{of} \mathrm{vernalization} \mathrm{and} \mathrm{translocation} \mathrm{of} \mathrm{the} \mathrm{stimulus.} \mathrm{J.} \mathrm{Exp.} \mathrm{Bot.} \mathrm{5:}$ $389-400$.

\section{PRZENOSZENIE EFEKTU INDUKCJI TERMICZNEJ ROZWOJU GENERATYWNEGO U RZEPAKU OZIMEGO 〈BRASSICA NAPUS VAR. OLEIFERA L. $\rangle$ NA DRODZE SZCZEPIENIA ROŚLIN}

\section{Streszczenie}

Badano możliwość przenoszenia czynnika warunkującego kwitnienie rzepaku ozimego z roślin wernalizowanych do roślin nie poddanych termicznej indukcji rozwoju generatywnego. W warunkach polowych wykonano kilkanaście serii szczepień zrazów pobranych z niewernalizowanych roślin rzepaku ozimego na roślinach wernalizowanych, będących w fazach rozwoju pąków i kwiatów. Niewernalizowane zrazy przejmowały zdolność do rozwoju generatywnego od wernalizowanych podkładek. Przekazywanie bodźca kwitnienia było bardziej efektywne w przypadku szczepień wykonanych $\mathrm{w}$ miejscu odcięcia wierzchołkowych części pędów, aniżeli w przypadku szczepień wykonanych z boku pędów. Stwierdzono, że aktywność czynnika kwitnienia u rzepaku ozimego po wernalizacji jest największa w fazie rozwoju pąków lub wcześniej. Natomiast największą wrażliwość na czynnik kwitnienia przejmowany z wernalizowanych podkładek wykazują zrazy 60-80 dniowe. Analiza zależności czasu trwania poszczególnych faz rozwoju generatywnego zrazów od wieku podkładek pozwala przypuszczać, że w wernalizowanych roślinach rzepaku ozimego istnieje więcej niż jeden przemieszczający się czynnik, warunkujący ich pełny rozwój generatywny. 